\title{
International Politics
}




\section{Books in the Politics Study Guides series}

British Government and Politics: A Comparative Guide Duncan Watts

International Politics: An Introductory Guide

Alasdair Blair and Steven Curtis

US Government and Politics: Second Edition

William Storey

Britain and the European Union

Alistair Jones

The Changing Constitution

Kevin Harrison and Tony Boyd

Democracy in Britain

Matt Cole

Devolution in the United Kingdom

Russell Deacon and Alan Sandry

Electoral Systems and Voting in Britain

Chris Robinson

The fudiciary, Civil Liberties and Human Rights

Steven Foster

Political Communication

Steven Foster

Political Parties in Britain

Matt Cole

The Politics of Northern Ireland

Joanne McEvoy

Pressure Groups

Duncan Watts

The Prime Minister and Cabinet

Stephen Buckley

The UK Parliament

Moyra Grant

The American Presidency

Duncan Watts 


\title{
International Politics
}

An Introductory Guide

\author{
Alasdair Blair and Steven Curtis
}

Edinburgh University Press 


\section{For Abbie, Jakob and William}

(C) Alasdair Blair and Steven Curtis, 2009

Edinburgh University Press Ltd

22 George Square, Edinburgh

www.euppublishing.com

Typeset in 11/13pt Monotype Baskerville by Servis Filmsetting Ltd, Stockport, Cheshire, and printed and bound in Great Britain by CPI Antony Rowe, Chippenham and Eastbourne

A CIP record for this book is available from the British Library

ISBN 9780748624157 (paperback)

The right of Alasdair Blair and Steven Curtis to be identified as authors of this work has been asserted in accordance with the Copyright, Designs and Patents Act 1988.

Published with the support of the Edinburgh University

Scholarly Publishing Initiatives Fund 